\title{
The Place of Local Radio in the Eradication of Harmful Widowhood Practices in North Central Nigeria
}

\author{
Prof. Okoro Nnanyelugo ${ }^{1}$, Ogwo, Comfort Ajuma $^{2 *}$ \\ ${ }^{1}$ Department of Mass Communication, University Of Nigeria, Nsukka, Enugu State, Nigeria \\ ${ }^{2}$ Department of Mass Communication, Kogi State University, Anyigba, Kogi State, Nigeria
}

*Corresponding Author: Ogwo, Comfort Ajuma, Department of Mass Communication, Kogi State University, Anyigba, Kogi State, Nigeria

\begin{abstract}
Development is impracticable in the face of discrimination. Harmful widowhood practices against women amount to a denial of women's rights. This study examined the place of local radio in the eradication of harmful widowhood practices in North Central Nigeria. It investigated the extent of practice, their exposure to local radio, the extent to which the radio programmes address the issue and its influence on the attitude of the people towards its eradication. The study was anchored on the agenda setting theory and the social responsibility theory. It employed the survey method and used the questionnaire to elicit data from selected elders, community leaders and widows. Analysis of the data collected showed that widows are still subjected to some harmful practices, that the local radio airs programmes that are geared towards its eradication infrequently and that these practices affect widows negatively. The study recommends that concerted efforts must be made by the government, NGOs, agencies and programme producers to produce and air programmes that will lead to the eradication of harmful widowhood practices in North Central Nigeria.
\end{abstract}

Keywords: Local Radio, Widowhood Practices, North Central Nigeria, Women's Rights

\section{INTRODUCTION}

The long sought world development cannot be achieved when human rights are trampled upon. The issue of discrimination against women's rights has been a long standing phenomenon that has defied several attempts at elimination. Anaeme $(2012$, p.1) states that "gender discrimination and violence against women are global phenomena as old as human history".

Women in the entire Nigerian society experience one form of gender discrimination or the other. Gender discrimination includes the following: child marriage, female genital mutilation, nutritional taboos, harmful widowhood practices, domestic violence, sexual freedom for husbands, bias land tenure systems and pattern of inheritance, lack of access to credit, family preference for sons, lack of participation in public decision-making, discrimination in housing and employment, discriminatory legislation, discriminatory religious practices, rape, battery, trafficking in women, murder, kidnapping and induced prostitution (Onyeukwu, 2014).

Harmful widowhood practices refer to a situation whereby widows are subjected to degrading humiliation, fetish discriminatory and traumatic practices when they lose their husbands. Some of such practices include drinking the water used to bath the corpse of their deceased husbands, compulsory shaving of hair, sitting and sleeping on bare floor throughout the mourning period, crying out at intervals, false imprisonment, sleeping with the corpse of the deceased husband, staying for some days without bathing, wife being inherited by the husbands' brother, denial of custody of her children and family property and in some places the widow must not take bath for some days and must not change her clothing. It is worthy of note that these practices are more prevalent in the rural communities. Unfortunately, rural women are ignorant of their rights and cannot question the rationality of these beliefs and practices and consciously or unconsciously endorse the perpetuation and ultimately infringement of their economic, social and cultural rights (Onyegu and Essiet 2002; Lockwood, 2006; Anaeme 2012). The men too, who are expected to give women their full rights, 
seem to be ignorant or better still not persuaded to change their attitude on the excuse that they are cultural practices.

The issue of harmful widowhood practices has defied various measures by both local and international organizations at curbing it. Internationally, one attempt to eradicate discrimination against women was the Convention to Eliminate All Forms of Discrimination against Women (CEDAW) which was adopted by UN General Assembly in 1979. The Convention spelt out areas wherein women are exposed to discrimination and committed countries to amend their law construct gender policies and create institutions to deliver them. Locally, among other instruments employed by the Nigerian government is the enactment of the Violence against Persons Prohibition (VAPP) Act which protects against harmful widowhood practices and other forms of violence or maltreatments against persons. In spite of these efforts, such harmful widowhood practices are still in practice especially in rural areas.

Radio has been adjudged the reliable medium for informing, educating and sensitizing rural populace on various issues. Its ability to bring attitudinal change among a group of people has been established. Despite the establishment and operation of local radios in North Central and its programmes, the issue of harmful widowhood practices still persists and this is blamed on ignorance. Is it that the radio is not airing programmes that are persuasive enough or that the people are not exposing themselves to such programmes? This investigation sought to establish the extent to which local radio has influenced the people's attitude towards widows and to equally suggest ways local radio can be made more effective for the eradication of harmful widowhood practices in North Central Nigeria.

This study covers the North Central Nigeria. North Central is one of the geo-political zones in northern Nigeria comprising Niger State, Benue State, Kogi State, Plateau State, Kwara State, Nassarawa State and the Federal Capital Territory. The current population of the region is 27,911,749 and it covers a surface area of $261,425 \mathrm{~km}^{2}$ ("List of Nigerian states", 2016). Its people practise Christianity, Islam and Traditional religion and are ardent observers of culture and tradition. ("The Violent Road: Nigeria's North Central", 2013).

\subsection{Objective of the Study}

This study set out to investigate the role of local radio in curbing harmful widowhood practices in North Central Nigeria. To achieve this, the research sought to answer the following research questions:

- To what extent do people in North Central Nigeria have access to local radio?

- To what extent are harmful widowhood practices enforced in North Central Nigeria?

- Do local radios in North Central Nigeria have programmes that focus on the eradication of harmful widowhood practices?

- To what extent has local radio programmes influenced the eradication of harmful widowhood practices in North Central Nigeria?

\subsection{Review of Related Literature}

Harmful widowhood practices refer to the situations where women are subjected to dehumanizing experiences at their husband's death. To further explicate the issue of harmful widowhood practices, Ifemeje and Umejiaka (2014) noted that under the Igbo culture, widows are subjected to all manner of degrading treatment. They are often the chief suspects on the death of their husbands and therefore were expected to go through fetish rituals in order to absolve themselves from complicity in their husbands' death. For instance, some Igbo customs demand widows to drink the water that was used to bath the corpse of their deceased husbands. This needless to say, compounds the psychological trauma widows are already passing through in consequence of their husbands' death. Other dehumanizing widowhood practices often meted out against widows include: compulsory shaving of hair, sitting and sleeping on bare floor throughout the mourning period, crying out at intervals and finally false imprisonment (the widows movement is usually restricted within the house, she is banned from trading within this lengthy mourning period, as a mark of respect for her deceased partner). Men 
under our custom are not subject to any of these degrading treatments. A wife could be inherited by the brother of her deceased husband.

Lending voice to this, Lewu $(2011$, p. 227) stated "in some cultures also, widows are shaved and cannot bathe until seven days after their husband's death. Besides, water used to wash the husbands' corpse has to be taken by the widows to prove that they were innocent of the men's death. It is not the case with widowers". She further noted that under the three systems operating in Nigeria, statutory, customary and Islamic, women face discrimination in matters of inheritance. A widow is entitled to one third of her late husband's property if there are children but if there are no children, she is entitled to half of his estate. However, this is far from the practice. Many widows with or without children have been dispossessed of their late husband's property by family members. Wife inheritance and other forms of widowhood malpractices practised in many parts of Nigeria debase women by reducing them to common property. In certain communities, widows are forced to drink water used in washing their husband's corpses to prove innocence and non complicity in husband's death. There is no national legislation on this but States like Edo, Anambra, Ebonyi, Ekiti, Enugu and Imo have Laws prohibiting this. But again none has been prosecuted and news of such wicked maltreatment constantly inundates our media (Opaluwa, 2013).

Eradicating the issue of harmful widowhood practices requires packaging radio contents that will inform and spur key participants, that is, the women and community leaders to take the issue seriously.

Lewu, M. A. Y (2011) conducted a research titled "Discrimination against Women in Nigeria: An Overview". The study examined the reasons for discrimination against women in Nigeria by highlighting the various ways discrimination manifests and their consequences. The methodological approach employed was the qualitative research method adopting interview and written works. It was discovered that social, cultural, political and economic factors account for the discrimination against women in all spheres of life. The paper concluded that for Nigeria to achieve democracy, development, growth and good health for her people, women must have maximum opportunities to realize their optimum potentials. The paper recommends that the public should be enlightened through programmes at all levels of government to stop harmful cultural practices through radio, television announcements, plays and dramas. Legal instruments should be provided to prosecute offenders. Religious organizations should promote morality and the dignity of womanhood, NGOs and CBOs promoting women's rights should be encouraged by the government, gender studies should be included in school curriculum and excessive use of drugs should be discouraged,

Ngambouk \& Mathias (2016) conducted a case study on "the social context of widowhood rites and women's human rights in Cameroon". The study examined the social logic of superstitious beliefs and associated fears sustaining the dehumanizing practice of widowhood rights and practices (WRP). The study combined ethnographic field work on harmful traditional practices and participant observation was concluded between October and December, 2009 in the Balengou community. Through systematic and purposeful sampling, 39 women and 8 male elders were interviewed. The findings of the study showed that the rites have negative effect on the women and therefore suggested that there be the strengthening of women's rights through gender-neutral marriage, succession and inheritance legislation based on notion of equality and social justice between the sexes and the harmonization of WRP.

A global study commissioned by the Loomba Foundation on widows in both developed and developing countries including Nigeria revealed among other things the extent of unfair treatment of widows in those countries. Seventeen countries were surveyed, twelve of which reported at least $40 \%$ of unfair treatment of widows in comparison with other women. The question asked to respondents drawn from the general public was, "to what degree are women who are widowed in your country treated worse than other women?" To a great deal, some, a little or not at all? On the average, only $29 \%$ of the respondents answered 'not at all'. The remaining $71 \%$ admitted that there was at least a little degree of unfair treatment of widows in their country. The result showed that unfair treatment of widows, including harmful traditional practices is in existence across several regions, societies and cultures in the world. (The Loomba Foundation, 2015). A summary report of the findings of the study is shown below: 


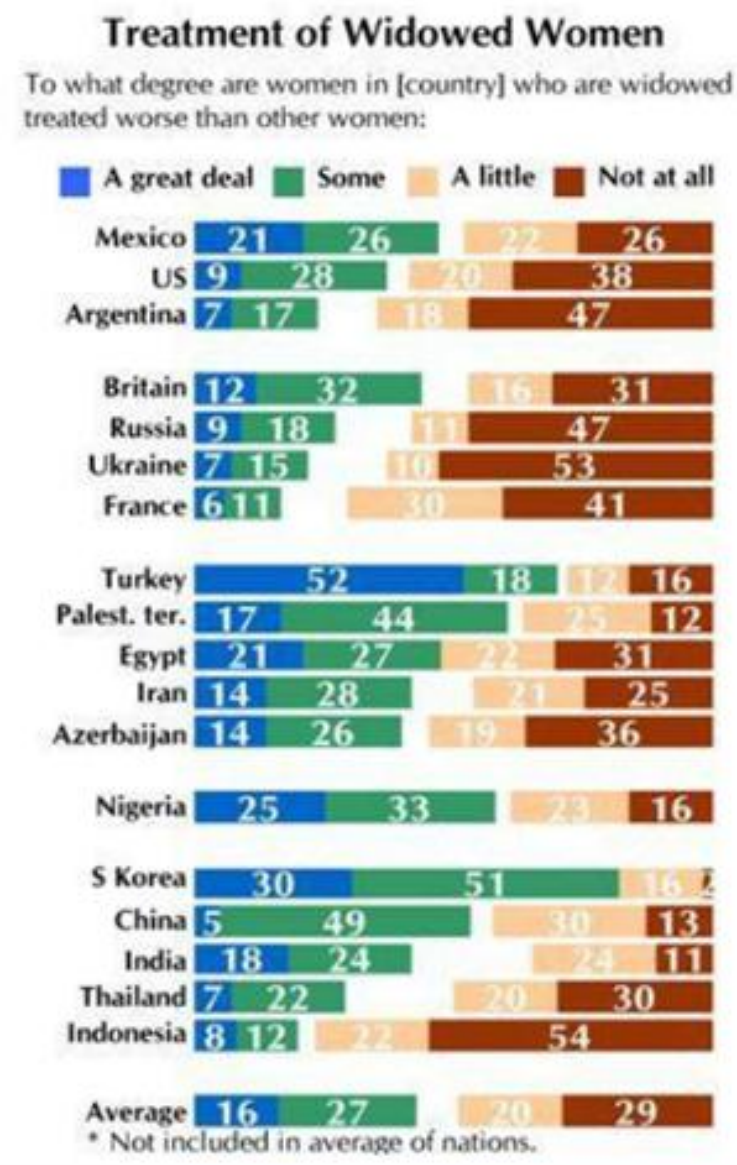

Source: The Loomba Foundation, 2015

\subsection{Theoretical Framework}

The theoretical anchors for this study are the agenda-setting theory and the social responsibility theory.

Agenda setting theory was propounded by Maxwell Mccombs and Donald Shaw in 1972/1973. They argued that the media may not be successful in telling us what to think, but they are stunningly successful in telling us what to think about and how to think about it. According to Folarin (1998, p.68) agenda setting theory implies that the media predetermined the issues to think about through headline, display pictures and layout in newspapers, magazines, films, graphics or timing on radio or television. This theory is relevant to this research because the issue of women's rights and war against harmful widowhood practices when set as agenda by the local radio will become an important issue for the people to think about which will foster a change in perception and action.

The second theory is the social responsibility theory of the press. This theory of the press has its origin tied to the Hutchins Commission of 1947 where stakeholders gathered to discuss the tenets of the libertarian theory of press, with emphasis on press freedom. This theory is relevant to this study because it places the media in a position to accept and fulfil certain obligations to society and in doing that, objectivity must be adhered to and attention must be given to the diversity of the society. This implies that the media (local radio) should accept and fulfil the obligations of objectively placing before the people the evils of discrimination against women rights and should be able to give the diversity of the society attention. This is to be seen and taken as a social responsibility for the media and such responsibility should be accurately handled.

\section{RESEARCH METHODOLOGY}

\subsection{Research Design}

The research design for this study is the survey. Survey is chosen because it gives opportunity to the researchers to conduct a realistic inquiry into media-audience relationships in terms of their disposition or attitude to issues. The study combined descriptive and analytical survey. 


\subsection{Population of the Study}

The population of this study comprises the entire North Central Nigeria. The population of the individual states in the North Central Zone from the 2006 National Population Census is as follows: Benue - 4,253,641, Kogi - 3,314,043, Kwara - 2,365,353, Nasarawa - 1,869,377, Niger - 3,954,772, Plateau - 3,206,531, FCT - 1,406,239, making a total population of 20,369,956 (National Population Commission, 2006). Based on a projected growth rate of $3.2 \%$, the current population of North Central Nigeria is $27,911,749$.

\subsection{Sample Size}

The sample size for this study is 384 . This was arrived at using the Chochran's formula for calculating sample size for a large population as shown below:

$$
n_{0}=\frac{z^{2} p q}{e^{2}}
$$

Where

$n_{0}=$ sample size

$z=z$ value corresponding to chosen confidence level

$p=$ degree of variability and

$e=$ desired level of precision

\subsection{Sampling Procedure}

This study adopted the multi-stage sampling procedure. The existing stratum of states was maintained. North Central Nigeria comprise Niger state, Kwara state, Kogi state, Nassarawa state, Benue state, Plateau state and the Federal Capital Territory. Two of the states were selected using the ballot system (Kogi State and Niger State). A local government each was then randomly selected from the two states (Olamaboro Local Government in Kogi State and Suleja Local Government in Niger State) and finally, a community each was purposively selected from the two local governments (Ogugu in Olamaboro Local Government of Kogi State and Angwan Rimi in Suleja Local Government of Niger State). These communities were selected based on the fact that they are rural communities and as such still maintain high regard for traditional and cultural practices. In each of the two communities, 192 copies of questionnaire were then distributed to purposively selected widows, community leaders and elderly ones.

\subsection{Research Instrument}

The research instrument for this study is the questionnaire. The questionnaire comprises two sections. The first section covers the demographic characteristics of the respondents while the second section is the body of the questionnaire covering questions on the subject matter. The Responses to the questionnaire were used to answer research questions and to prove the hypothesis.

\subsection{Validation of Instrument}

The pre-test and validation of the research instrument was done in one week. Twenty respondents were involved.

\subsection{Reliability Test}

The test - retest method was adopted to establish the reliability of the instrument. The questionnaire was administered to the same group of 20 respondents from the population of study on two occasions in an interval of two weeks. The results were collated and the correlation coefficient of the two sets of data was computed. The value of the Spearman's rank correlation coefficient for the two sets of data was 0.9607 . This shows that there is a high level of association between the two sets of data and hence shows the reliability of our instrument.

\subsection{Method of Data Collection}

The researcher in company of two research assistants self-administered the questionnaire over a period of three days in each of the two communities and retrieved them immediately. 


\subsection{Method of Data Analysis}

Data collected about the demography of respondents is presented and analyzed using pie charts. Other data collected from the questionnaire were analysed using the Likert's scale. A five point Likert's scale was used and the responses were combined into two categories: "accepted" and "rejected" based on the value of the weighted mean for each response.

\section{RESUlTS \& DISCUSSION}

\subsection{Demographic Characteristics of Respondents}

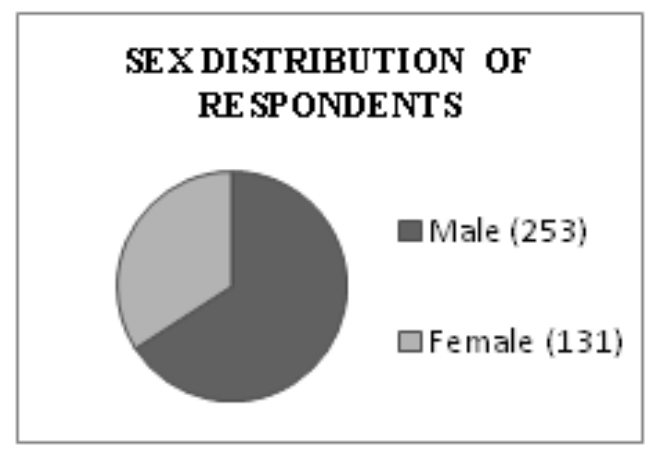

Chart 1

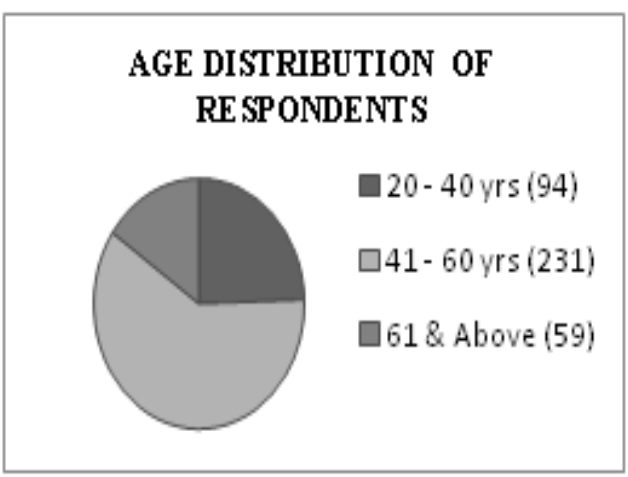

Chart 2

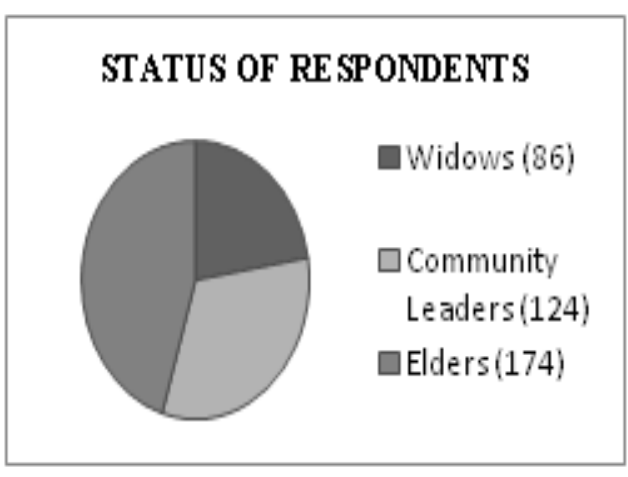

Chart 3

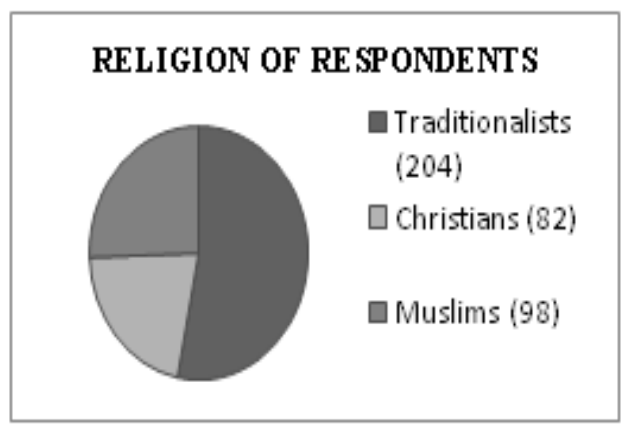

Chart 4 
Table1. Extent of access to local radio

\begin{tabular}{|l|l|l|l|l|l|l|l|l|}
\hline S/N & Items & $\begin{array}{l}\text { Strongly } \\
\text { Agree } \\
\text { SA) }\end{array}$ & $\begin{array}{l}\text { Agree } \\
(\mathbf{A})\end{array}$ & $\begin{array}{l}\text { Undecided } \\
\text { (UD) }\end{array}$ & $\begin{array}{l}\text { Disagree } \\
\text { (D) }\end{array}$ & $\begin{array}{l}\text { Strongly } \\
\text { Disagree } \\
\text { (SD) }\end{array}$ & $\begin{array}{l}\text { Weighted } \\
\text { Mean } \\
\text { (WMS) }\end{array}$ & Decision \\
\hline 1. & I have access to a local radio & 319 & 65 & 0 & 0 & 0 & 4.8 & Accepted \\
\hline 2. & I listen to the radio & 279 & 105 & 0 & 0 & 0 & 4.7 & Accepted \\
\hline 3. & I often listen to the radio & 160 & 118 & 18 & 50 & 38 & 3.8 & Accepted \\
\hline
\end{tabular}

Table2. Extent of harmful widowhood practices in North Central Nigeria

\begin{tabular}{|c|c|c|c|c|c|c|c|c|}
\hline $\mathbf{S} / \mathbf{N}$ & Items & $\begin{array}{l}\text { Strongly } \\
\text { Agree } \\
(\text { SA })\end{array}$ & $\begin{array}{l}\text { Agree } \\
\text { (A) }\end{array}$ & $\begin{array}{l}\text { Undecided } \\
\text { (UD) }\end{array}$ & $\begin{array}{l}\text { Disagree } \\
\text { (D) }\end{array}$ & $\begin{array}{l}\text { Strongly } \\
\text { Disagree } \\
\text { (SD) }\end{array}$ & \begin{tabular}{|l|} 
Weighted \\
Mean \\
$($ WMS $)$ \\
\end{tabular} & Decision \\
\hline 4. & $\begin{array}{l}\text { Widows are subjected to some } \\
\text { harmful practices in my } \\
\text { community }\end{array}$ & 283 & 101 & 0 & 0 & 0 & 4.7 & Accepted \\
\hline 5. & $\begin{array}{l}\text { Widows are made to shave } \\
\text { their hair at the death of their } \\
\text { husbands }\end{array}$ & 184 & 81 & 30 & 16 & 73 & 3.7 & Accepted \\
\hline 6. & $\begin{array}{l}\text { To prove their innocence, they } \\
\text { are sometimes compelled to } \\
\text { drink the water used to bath } \\
\text { their husbands }\end{array}$ & 61 & 30 & 152 & 31 & 110 & 2.7 & Rejected \\
\hline 7. & $\begin{array}{l}\text { Widows are compelled to sleep } \\
\text { on the floor during the period } \\
\text { of mourning }\end{array}$ & 203 & 91 & 36 & 36 & 18 & 4.1 & Accepted \\
\hline 8. & $\begin{array}{l}\text { Widows are inherited by late } \\
\text { husband's brothers }\end{array}$ & 65 & 50 & 101 & 57 & 111 & 2.7 & Rejected \\
\hline 9. & $\begin{array}{l}\text { Widows don't carry out } \\
\text { economic activities during the } \\
\text { period of mourning }\end{array}$ & 155 & 88 & 55 & 65 & 21 & 3.8 & Accepted \\
\hline 10. & $\begin{array}{l}\text { Widows are denied their } \\
\text { husband's properties }\end{array}$ & 155 & 121 & 37 & 50 & 21 & 3.9 & Accepted \\
\hline 11. & $\begin{array}{l}\text { Sometimes, their children are } \\
\text { taken away from them }\end{array}$ & 85 & 76 & 162 & 40 & 21 & 3.4 & Accepted \\
\hline
\end{tabular}

Table3. Local radio programmes that focus on eradicating harmful widowhood practices

\begin{tabular}{|l|l|l|l|l|l|l|l|l|}
\hline S/No & Items & $\begin{array}{l}\text { Strongly } \\
\text { Agree } \\
\text { (SA) }\end{array}$ & $\begin{array}{l}\text { Agree } \\
(\mathbf{A})\end{array}$ & $\begin{array}{l}\text { Undecided } \\
\text { (UD) }\end{array}$ & $\begin{array}{l}\text { Disagree } \\
\text { (D) }\end{array}$ & $\begin{array}{l}\text { Strongly } \\
\text { Disagree } \\
\text { (SD) }\end{array}$ & $\begin{array}{l}\text { Weighted } \\
\text { Mean } \\
\text { (WMS) }\end{array}$ & \begin{tabular}{l} 
Decision \\
\hline 12.
\end{tabular} \\
$\begin{array}{l}\text { The local radio airs programmes } \\
\text { that focus on the eradication of } \\
\text { harmful widowhood practices }\end{array}$ & 82 & 53 & 101 & 66 & 82 & 3.0 & Accepted \\
\hline 13. & The programmes are aired often & 23 & 36 & 120 & 131 & 74 & 2.5 & Rejected \\
\hline 14. & $\begin{array}{l}\text { The programmes are aired in } \\
\text { the local language }\end{array}$ & 51 & 151 & 85 & 41 & 3.0 & Accepted \\
\hline
\end{tabular}

Table4. Influence of the radio programmes on the eradication of harmful widowhood practices in North Central Nigeria

\begin{tabular}{|l|l|l|l|l|l|l|l|l|}
\hline S/No & Items & $\begin{array}{l}\text { Strongly } \\
\text { Agree } \\
\text { (SA) }\end{array}$ & $\begin{array}{l}\text { Agree } \\
(\mathbf{A})\end{array}$ & $\begin{array}{l}\text { Undecided } \\
\text { (UD) }\end{array}$ & $\begin{array}{l}\text { Disagree } \\
\text { (D) }\end{array}$ & $\begin{array}{l}\text { Strongly } \\
\text { Disagree } \\
\text { (SD) }\end{array}$ & $\begin{array}{l}\text { Weighted } \\
\text { Mean } \\
\text { (WMS) }\end{array}$ & Decision \\
\hline 15. & $\begin{array}{l}\text { The programmes have influenced } 39 \\
\text { the harmful widowhood practices } \\
\text { in my community }\end{array}$ & 71 & 94 & 100 & 80 & 2.7 & Rejected \\
\hline 16. & $\begin{array}{l}\text { There has been great reduction } \\
\text { in the adoption of such harmful } \\
\text { widowhood practices a result } \\
\text { of the radio programmes }\end{array}$ & 33 & 71 & 220 & 40 & 2.4 & Rejected \\
\hline 17. & $\begin{array}{l}\text { Harmful widowhood practices } \\
\text { have negative impact on the } \\
\text { women folk. }\end{array}$ & 30 & 26 & 93 & 30 & 3.7 & Accepted \\
\hline
\end{tabular}




\section{DISCUSSION}

Based on the analysis of data gathered, it is evident that harmful widowhood practices still exist in North Central Nigeria because all the respondents accepted that widows in their communities are subjected to one form of harmful widowhood practice or the other.

The responses to questions targeted at research question two as presented in Table 2 indicates that widows are still subjected to some form of harmful practices which are dehumanizing at the death of their husbands. This agrees with Ifemeje \& Umejiaku (2014, p.20) where they have this to say:

...this harmful widowhood practice is an infraction of the widow's right to dignity of human person. Furthermore, the restriction of the widow's right to movement is a breach of her right to movement and amounts to false imprisonment. Finally, it is equally a serious infraction of the widow's right to freedom from discrimination in the sense that these obnoxious traditional mourning rites target only women.

This study also revealed that respondents have access to local radio and that they are highly exposed to it. Responses to questions under research question one as presented in Table 1 clearly reveals that the people have access to local radio and they often listen to it. This implies that radio as a medium is still relevant in disseminating information to rural dwellers in North Central Nigeria.

Findings from this research also showed that the local radio air programmes that focus on the eradication of harmful widowhood practices and this is done in the local language but not at all times. Also, these programmes are not aired often. This is evident from responses to questions presented in Table 4 above. The fact that these programmes are not aired often reduces the prominence given to such a delicate and serious matter. It reveals why these practices have persisted in North Central Nigeria. The simple reason is that the prominence that should be given to the issue by frequency of broadcast and timing was not given to it. This is contrary to how the radio was used in Malawi and Uganda in their fight against child labour. In Malawi, apart from CRECOM, the story workshop, an educational and creative centre for community sensitization joined forces with the government of Malawi and donors to set up the fight against child labour through a new episode radio soap opera titled "Tilitonse Tisazunze Ana" (Don't exploit children). (Anonymous cited in Asogwa \& Ogwo)

In Uganda, to achieve the elimination of child labour in tobacco growing, the radio was used to create awareness through different radio spots aired over 1000 times on Masinidi Broadcasting Service (MBS) and Radio Kitara. Messages were aired mainly during the peak season of planting, harvesting and marketing. Five radio programmes were developed and broadcast. Four radio drama performances were conducted, three talk shows were aired, phone-in-programmes were conducted and 756 spot messages were broadcast in four languages. About 9000 communities were reached to an estimated listenership of 2 million people and as a result of the radio programmes, farmers with the knowledge of the law prohibiting child labour drastically increased from $36 \%$ in 2006 to almost $80 \%$ in 2009 . (ECLT Foundation cited in Asogwa \& Ogwo)

The records above give explicit information on how the radio is a powerful medium that can be used to inform, sensitize and create behavioural change among rural communities and by implication, the issue of harmful widowhood practices in North Central Nigeria can be reduced to the barest minimum if not totally eradicated using the local radio.

Responses to questions targeted at unveiling the influence of local radio on the eradication of harmful widowhood practices in North Central Nigeria as presented in Table 5 shows that the radio programmes have not influenced the eradication of harmful widowhood practices in any significant measure.

\section{CONCLUSION}

This study investigated the place of the local radio in the eradication of harmful widowhood practices in North Central Nigeria. Its findings revealed that some humiliating practices are meted against women when they lose their husbands and that the radio which is a strong weapon for educating the people is not maximally utilized as they do not have enough programmes on the issue and the local languages are not used for all programmes, making it difficult for rural dwellers who are majorly illiterates to understand. Hence, no significant influence of the radio programmes on the people's action towards widows. 
The study therefore concludes that the radio be put to full utilization in the fight to eradicate all harmful practices against the widows in North Central Nigeria as its persistence will hinder development.

\section{RECOMMENDATIONS}

To achieve the eradication of all forms of harmful widowhood practices in North Central Nigeria through the radio, the following are recommended.

- Government should sponsor public enlightenment programmes through local radio announcements, drama, soap-operas and phone-in programmes that will give room for the people's participation in issues that touch them.

- Local radio programme producers should set agenda for the issue of eradicating harmful widowhood practices in North Central by the selection of programmes, use of local language, frequency of airing and the time of airing.

- NGOs should also collaborate with the Federal Ministry of Women Affairs to sponsor publicities, public enlightenments and advocacy on radio.

- Persuasive public interest advertisements should be aired on radio for the eradication of harmful widowhood practices by governmental and non governmental agencies.

- Community radio listening centres should be organized by the government focusing on eradicating harmful widowhood practices.

- Radio stations should package spot messages in local languages as this will create understanding and compliance.

\section{REFERENCES}

[1] Agboh, C. (2012). Women participation in Politics: Role of the Media. KSU Journal of Mass Communication. 1(2), $105-120$.

[2] Anaeme, F. O. (2012). Reducing Gender Discrimination and Violence against Women through Library and Information Services in Library Philosophy and Practice. Retrieved from http://willib.uni.edu/ LPP/p1-7

[3] Asemah, E. S., Anum, V. and Edogoh, L. O. (2013). Radio as tool for Rural Development in Nigeria: Prospects and Challenges. Affrev Ijah, An International Journal of Arts and Humanities, 2(1), 17 - 35.

[4] Asogwa, C. E. and Ogwo, C. A. (2014). The Place of Local Media in Addressing the Child Labour Phenomenon in Anyigba Community: A study of Radio Kogi Ochaja. Global Journal of Interdisciplinary Social Sciences, 3(5), $105-113$.

[5] Ciroma, I. M. (2016). $6^{\text {th }}$ Century Periodic Report on the implementation of the Convention on the Elimination of all Forms of Discrimination against Women (CEDAW)

[6] Folarin, B. (1998). Theories of Mass Communication: An Introductory Text. Ibadan: Stiling Holden Publishers.

[7] Gallagher, M. (1979). The Portrayal and Participation Opportunities: The case of Women and the Media. Paris: UNESCO

[8] Ifemeje, S. C. and Umejiaka, N. (2014). Discriminatory Cultural Practices and Women's Rights among the Igbos of South-East Nigeria: A Critique. Journal of Law Policy and Globalization, 25, 18 - 27.

[9] Lewu, M. A. Y (2011). Discrimination against Women in Nigeria: An Overview. Ilorin Journal of History and International Studies, 2(2), 225 - 243.

[10] List of Nigerian states by area. (2016). Retrieved January 30, 2017, from Wikipedia: https://en.wikipedia.org/wiki/List_of_Nigerian_states_by_area

[11] Lockwood, B. W. (Ed) (2006). Women's Rights: A Human Rights Quarterly Reader. Baltimore: John Hopkins University Press.

[12] McQuail, D. (1989). Mass Communication Theory: An Introduction. London: Sage Publishers

[13] National Population Commission. (2006). 2006 Population and Housing census of the Federal Republic of Nigeria Priority Tables Volume 1. Retrieved from http://catalog.ihsn.org/index.php/catalog/3340/ download $/ 48519$

[14] Ngambouk, V. P. and Mathias, F. A. (2016). The social context of widowhood rites and women's human rights in Cameroon. Cogent Social Sciences, 2(1). Retrieved from http://dx.doi.org/10.1080/23311886. 2016.1234671 
[15] Onyegu, R. and Essiet, J. (2002). Update on Women's Socio-Economic Rights in Nigeria. Lagos: Shelter Rights Initiative.

[16] Onyeukwu, O. (2014). Traditional rulers as positive change agents of gender based biases. In O. Nwankwo \& K. Onukwube (Eds.), The Gender Dimensions of Culture (pp. 90-98). Enugu: Fourth Dimension Publishers

[17] Opaluwa, A. D. (2013). The Effect of Cultural Practices and Traditional Beliefs on the Human Rights of Women in Igala Land. Unpublished Masters Dissertation, Kogi State University, Anyigba.

[18] Shah, A. (2010). Women's Rights. Retrieved from http://www.globalissues.org/article/166/womens-rights

[19] The Loomba Foundation. (2015). The Global Widows Report 2015 - A Global Overview of Deprivation faced by Widows and their Children. Retrieved from the Loomba Foundation website: http://theloombafoundation.org/wp-content/uploads/2015/07/Loomba-Foundation-Global-Widows-FULLReport-2015-V2.2.pdf

[20] The Violent Road: Nigeria's North Central. (2013). Retrieved February 14, 2017, from AOAV website: https://aoav.org.uk/2013/the-violent-road-nigeria-north-central/

Citation: Prof. Okoro Nnanyelugo, Ogwo, Comfort Ajuma. "The Place of Local Radio in the Eradication of Harmful Widowhood Practices in North Central Nigeria". International Journal of Media, Journalism and Mass Communications (IJMJMC), vol 4, no. 2, 2018, pp. 19-28. doi:http://dx.doi.org/10. 20431/24550043.0402003

Copyright: (C) 2018 Authors. This is an open-access article distributed under the terms of the Creative Commons Attribution License, which permits unrestricted use, distribution, and reproduction in any medium, provided the original author and source are credited. 